\title{
PENGEMBANGAN SUBJEK SPECIFIK PEDAGOGIK (SSP) PRAKTIKUM IPA TERPADU SMP/MTS BERBASIS HOME MATERIALS TERHADAP MOTIVASI BELAJAR SISWA
}

\author{
Nanang Rahman, M.Pd \\ Dosen Program Studi PGSDUniversitas Muhammadiyah Mataram \\ nang_rhm@yahoo.com
}

\section{INFO ARTIKEL}

Riwayat Artikel:

Diterima: 18 - 11 - 2017

Disetujui: 02 - 12 - 2017

\section{Kata Kunci:}

1. Subjek Specifik Pedagogik

2. Praktikum IPA Terpadu

3. Home Materials

4. Motivasi Belajar

\begin{abstract}
ABSTRAK
Abstrak: Penelitian ini bertujuan untuk (1) mengetahui kualitas perangkat Subject Specific Pedagogy (SSP) Praktikum IPA terpadu berbasis home materials yang dikembangkan, (2) mengetahui pengaruh perangkat Subject Specific Pedagogy (SSP) Praktikum IPA terpadu berbasis home materials yang dikembangkan terhadap motivasi belajar siswa. Metode penelitian yang digunakan adalah penelitian dan pengembangan (R\&D) dengan 2 tahapan utama, yaitu pengembangan produk dan validasi produk yang dilakukan oleh ahli dan pendidik. Untuk mengetahui kualitas perangkat yang dikembangkan mengunakan instrumen angket kelayakan produk, sedangkan untuk mengetahui pengaruhnya terhadap motivasi beajar siswa menggunakan angket yang diberikan sebelum dan setelah perlakukan. Berdasarkan hasil penelitian dapat disimpulkan (1) berdasarkan penilaian ahli dan pendidik terhadap produk buku petunjuk praktikum IPA terpadu berbasis home materials dapat disimpulkan bahwa produk hasil pengembangan dikategorikan sangat baik sehingga layak untuk digunakan. (2) terdapat pengaruh yang signifikan antara nilai rata-rata angket motivasi peserta didik yang menggunakan buku petunjuk praktikum berbasis home materials (kelas treatment) dengan yang tanpa menggunakan buku petunjuk praktikum berbasis home materials (kelas kontrol).
\end{abstract}

\section{A. LATAR BELAKANG}

Pendidikan IPA diarahkan melalui proses inkuiri sehingga dapat membantu siswa untuk memperoleh pemahaman yang lebih mendalam tentang alam sekitar. Proses pembelajaran secara inkuiri dapat dilakukan melalui pengamatan alam sekitar atau dengan melakukan praktikum di dalam laboratorium. Berdasarkan hasil penelitian yang telah dilakukan oleh Bambang Sumintono (2010), menunjukan gejala bahwa kemampuan guru dalam mengelola kegiatan laboratorium masih kurang, dan frekuensi penggunaan laboratorium masih rendah karena keterbatasan alat dan bahan praktikum serta rendahnya kemampuan guru dalam melaksanakan kegiatan praktikum. Hal tersebut juga sesuai dengan penelitian yang telah dilakukan oleh Nanang Rahman (2016), menunjukkan bahwa guru mengalami kesulitan dalam melakukan kegiatan praktikum, khususnya yang menggunakan bahan dari lingkungan sekitar rumah (home materials). Penyebabnya karena keterbatasan kemampuan guru dalam menggunakan model pembelajaran yang sesuai serta kurangnya perangkat pembelajaran yang sesuai dalam kegiatan praktikum tersebut. Penggunaan bahan praktikum berbasis home materials memerlukan keterampilan khusus dari guru dalam melakukan menejemen pengelolaan kelas dan pengunaan bahan praktikum.

Keberadaan perangkat pembelajaran sangat diperlukan guna menunjang keberhasilan tujuan pembelajaran yang diharapkan. Namun, perangkat pembelajaran yang dimaksud belum tersedia di lapangan dan kebanyakan guru IPA juga belum mampu untuk menyusunnya. Kebanyakan guru hanya menggunakan buku sains atau buku petunjuk praktikum yang banyak dijual di pasaran yang biasanya menggunakan pedoman praktikum dengan alat dan bahan yang sulit didapatkan di sekolah-sekolah daerah terpencil. Oleh karena itu, perlu dilakukan penelitian guna mengembangkan perangkat Subject Specific Pedagogy (SSP) dalam kegiatan praktikum berbasis home materials yang dapat meningkatkan motivasi belajar siswa. Perangkat SSP yang akan dikembangkan meliputi: Rencana Pelaksanaan Pembelajaran, Petunjuk Praktikum berbasis home materials dan instrument penilaian. Perangkat SSP yang akan dikembangkan hanya terbatas pada materi kelas VIII yang memiliki tema eksperimentatif yang dapat dikembangkan dengan kegiatan praktikum. Materi IPA 
Terpadu kelas VIII memiliki banyak tema eksperimentatif sehingga dapat dikembangkan untuk membentuk karakter siswa. Penelitian ini bertujuan untuk mengetahui kualitas perangkat Subject Specific Pedagogy (SSP) Praktikum IPA terpadu berbasis home materials yang dikembangkan, (2) mengetahui pengaruh perangkat Subject Specific Pedagogy (SSP) Praktikum IPA terpadu berbasis home materials yang dikembangkan terhadap motivasi belajar siswa.

\section{B. METODE PENELITIAN}

\section{Tahapan Penelitian Pengembangan}

Prosedur pengembangan yang digunakan dalam penelitian dan pengembangan ini adalah pengembangan secara prosedural dimana langkah-langkahnya dijelaskan secara kongkrit dan rinci. Subject Specific Pedagogy IPA terpadu SMP/MTS berbasis home materials yang dikembangkan hanya terbatas pada materi pokok yang dapat menggunakan alat dan bahan alternatif, oleh sebab itu tidak semua materi IPA terpadu dapat dipraktikumkan dengan menggunakan bahan dan alat alternatif. Prosedur pengembangan yang dilakukan mengacu kepada prosedur Borg \& Galls.

\section{Lokasi Penelitian (Uji Coba Produk)}

Setelah produk pengembangan SSP IPA Terpadu SMP dalam kegiatan praktikum berbasis home materials divalidasi dan dinyatakan layak oleh ahli materi, ahli media, dan ahli kurikulum, maka selanjutnya produk tersebut diujicobakan kepada subjek uji coba (siswa). Subjek penelitian untuk uji coba produk yang dikembangkan dalam penelitian ini adalah siswa Sekolah Menegah Pertama (SMP) di Kabupaten Lombok Barat.

\section{Teknik Pengumpulan Data}

Untuk menghasilkan produk yang berkualitas diperlukan teknik pengumpulan data dan instrumen yang mampu menggali data yang diperlukan dalam pengembangan SSP IPA terpadu SMP dalam kegiatan praktikum berbasis home materials. Teknik pengumpulan data dengan angket. Instrumen yang digunakan untuk mengumpulkan data pada penelitian ini berupa lembar kuesioner kelayakan produk dan angket motivasi.

\section{Analisis Data}

Data yang diperoleh melalui kegiatan uji coba diklasifikasikan menjadi dua, yakni data kualitatif dan kuantitatif. Data kualitatif yang berupa kritik/masukan dan saran yang dikemukakan oleh ahli media, ahli materi, dan pendidik dikumpulkan untuk memperbaiki perangkat yang telah dikembangkan. Sedangkan data kuantitatif berupa hasil penilaian produk, dan angket motivasi.

\section{HASIL DAN PEMBAHASAN}

\section{Kelayakan Produk}

Data yang diperoleh dalam penelitian pengembangan buku petunjuk praktikum ini merupakan data hasil validasi yang dilakukan oleh ahli dan data penilaian yang dilakukan oleh pendidik serta peserta didik. Data hasil validasi dan penilaian juga dilengkapi dengan masukan serta komentar terhadap produk yang dikembangkan

Tujuan validasi ahli adalah untuk memberikan nilai dan menentukan kelayakan dari perangkat pembelajaran yang telah dikembangkan. Penilaian yang dilakukan oleh pendidik dan peserta didik adalah untuk mendapatkan nilai terhadap produk yang dikembangkan. Validasi dan penilaian juga bertujuan untuk memperoleh komentar dan saran, baik secara tertulis maupun lisan dengan cara berdiskusi tentang buku petunjuk praktikum IPA terpadu berbasis home materials. Rekap hasil validasi oleh 2 orang ahli dan penilaian oleh 4 orang pendidik.

Tabel 1.

Hasil penilaian ahli dan pendidik

\begin{tabular}{|l|l|c|l|}
\hline No & Aspek yang Dinilai & Ahli & Pendidik \\
\hline I & $\begin{array}{l}\text { Penulisan dan organisasi buku } \\
\text { petunjuk praktikum }\end{array}$ & 9,00 & 8,50 \\
\hline II & Kebenaran konsep dan materi & 13,00 & 13,50 \\
\hline III & $\begin{array}{l}\text { Kejelasan kalimat dan tingkat } \\
\text { keterbacaan }\end{array}$ & 9,00 & 8,50 \\
\hline IV & $\begin{array}{l}\text { Tingkat keterlaksanaan kegiatan } \\
\text { praktikum }\end{array}$ & 9,00 & 9,25 \\
\hline V & Evaluasi hasil praktikum & 11,00 & 10,00 \\
\hline VI & $\begin{array}{l}\text { Tampilan fisik buku petunjuk } \\
\text { praktikum }\end{array}$ & 9,00 & 9,25 \\
\hline VII & Aspek karakter & 5,00 & 5,00 \\
\hline
\end{tabular}

Grafik hasil penilaian ahli dan pendidik terhadap produk buku petunjuk praktikum IPA terpadu berbasis Home Materials untuk pembentukan karakter peserta didik.

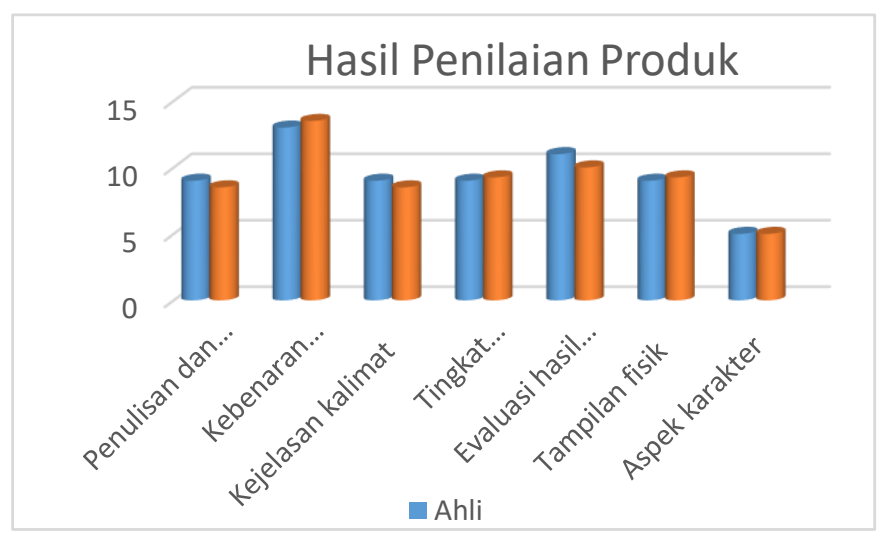

Gambar 1. Hasil Penilaian Produk 
Berdasarkan hasil penilaian yang dilakukan oleh ahli dan pendidik terhadap produk buku petunjuk praktikum IPA Terpadu berbasis home materials, maka dapat diuraikan sebagai berikut: (1) aspek penulisan dan organisasi buku petunjuk praktikum mendapatkan mendapatkan nilai $\mathrm{A}$ sehingga termasuk kategori sangat baik, (2) aspek kebenaran konsep dan materi mendapatkan nilai A sehingga termasuk kategori sangat baik, (3) aspek kejelasan kalimat dan tingkat keterbacaan mendapatkan nilai A sehingga termasuk kategori sangat baik, (4) aspek tingkat keterlaksanaan kegiatan praktikum mendapatkan nilai A sehingga termasuk kategori sangat baik, (5) aspek evaluasi hasil praktikum mendapatkan nilai B sehingga termasuk kategori baik, (6) aspek tampilan fisik buku petunjuk praktikum mendapatkan nilai A sehingga termasuk kategori sangat baik, (7) aspek karakter mendapatkan nilai A sehingga termasuk kategori sangat baik. Berdasarkan penilaian ahli dan pendidik terhadap produk buku petunjuk praktikum IPA terpadu berbasis home materials dapat disimpulkan bahwa produk hasil pengembangan dikategorikan sangat baik sehingga layak untuk digunakan.

\section{Motivasi Belajar}

Adapun data hasil motivasi peserta didik sebelum maupun sesudah menggunakan buku petunjuk praktikum berbasis home materials di kelas treatment serta di kelas kontrol yang diperoleh dari angket mengenai motivasi belajar peserta didik dapat dilihat pada Tabel 2 .

Tabel 2

\section{Ringkasan Data Angket Motivasi Peserta Didik}

\begin{tabular}{|c|c|c|c|c|c|c|}
\hline \multirow{2}{*}{} & \multicolumn{6}{|c|}{$\begin{array}{c}\text { Angket Motivasi Peserta Didik } \\
\text { (skala 0-5) }\end{array}$} \\
\cline { 2 - 7 } & \multicolumn{2}{|c|}{ Kelas Kontrol (KK) } & \multicolumn{2}{c|}{ Kelas Treatment (KT) } \\
\cline { 2 - 7 } & $\begin{array}{c}\text { Seb } \\
\text { elu } \\
\text { m }\end{array}$ & $\begin{array}{c}\text { Sesu } \\
\text { dah }\end{array}$ & $\begin{array}{c}\text { Gain } \\
\text { Stand } \\
\text { ar }\end{array}$ & $\begin{array}{c}\text { Sebel } \\
\text { um }\end{array}$ & $\begin{array}{c}\text { Sesu } \\
\text { dah }\end{array}$ & $\begin{array}{c}\text { Gain } \\
\text { Stand } \\
\text { ar }\end{array}$ \\
\hline Rerata & $\begin{array}{c}3,1 \\
6\end{array}$ & 3,35 & 0,11 & 3,26 & 4,04 & 0,45 \\
\hline $\begin{array}{c}\text { Standar } \\
\text { Deviasi }\end{array}$ & $\begin{array}{c}0,1 \\
9\end{array}$ & 0,20 & 0,09 & 0,15 & 0,19 & 0,13 \\
\hline
\end{tabular}

Berdasarkan Tabel 2, dapat dilihat bahwa rerata motivasi sebelum kedua kelas yaitu 3,16 untuk KK dan 3,26 untuk KT. Untuk motivasi sesudah, Rerata motivasi sesudah kedua kelas yaitu 3,35 untuk KK dan 4,04 untuk KT. Rerata KT lebih tinggi dibanding KK dengan selisih 0,69.

\section{- Uji Hipotesis}

Untuk mengetahui ada tidaknya perbedaan motivasi peserta didik antara kelas Treatment dan kelas Kontrol maka dilakukan perhitungan dengan menggunakan uji statistik Independent sample t-test dengan menggunakan program SPSS 17.0. Secara singkat hasil perhitungan Independent sample t-test dapat dilihat pada Tabel 10.
Tabel 3.

Uji Perbedaan Motivasi Peserta Didik

\begin{tabular}{|l|c|c|c|}
\hline \multirow{2}{*}{ Motivasi peserta didik } & $\mathrm{T}$ & $\mathrm{df}$ & $\begin{array}{c}\text { Sig.(2- } \\
\text { tailed) }\end{array}$ \\
\cline { 2 - 4 } & 13,335 & 56 & 0,000 \\
\hline $\begin{array}{l}\text { Equal variances } \\
\text { assumed }\end{array}$ & 13,335 & 55,917 & 0,000 \\
\hline $\begin{array}{l}\text { Equal variances not } \\
\text { assumed }\end{array}$ & \multicolumn{3}{|c|}{} \\
\hline
\end{tabular}

Berdasarkan Tabel 3 di atas tampak bahwa nilai uji t untuk perbedaan angket motivasi peserta didik adalah 13,335 dengan Sig (2-tailed) $=0,000$. Berdasarkan data di atas karena sig (2-tailed) $<0,05$ yaitu $0,000<0,05$ maka $\mathrm{H}_{0}$ ditolak dan $\mathrm{H}_{a}$ diterima. Berdasarkan hal tersebut dapat simpulkan bahwa terdapat pengaruh yang signifikan antara nilai rata-rata angket motivasi peserta didik yang menggunakan buku petunjuk praktikum berbasis home materials (kelas treatment) dengan yang tanpa menggunakan buku petunjuk praktikum berbasis home materials (kelas kontrol).

\section{SIMPULAN DAN SARAN}

Berdasarkan hasil penelitian yang telah dilakukan, maka dapat disimpulkan sebagai berikut:

1. Berdasarkan penilaian ahli dan pendidik terhadap produk buku petunjuk praktikum IPA terpadu berbasis home materials dapat disimpulkan bahwa produk hasil pengembangan dikategorikan sangat baik sehingga layak untuk digunakan.

2. Terdapat pengaruh yang signifikan antara nilai rata-rata angket motivasi peserta didik yang menggunakan buku petunjuk praktikum berbasis home materials (kelas treatment) dengan yang tanpa menggunakan buku petunjuk praktikum berbasis home materials (kelas kontrol).

\section{DAFTAR RUJUKAN}

[1] Anik Ghufron, Widyastuti Purbani, \& Sri Sumardiningsih. (2007). Panduan: Penelitian dan pengembangan. Yogyakarta: Lembaga Penelitian Universitas Negeri Yogyakarta.

[2] Borg, W. R. \& Gall, M. D. (1983). Educational research: An introduction ( $4^{\text {th }}$ ed). New York: Longman Inc.

[3] Bryce, T.G.K., J. McCall, J. MacGregor, I.J. Robertson, \& R.A.J. Weston. (1990). Techniques for Assesing Process Skills in Practical Science: Teacher's Guide. Oxford: Heinemann Educational Books.

[4] California State University. (2007). Effective Teaching. California: California State University Northtridge.

[5] Nana Syaodih Sukmadinata. (2007). Metode penelitian pendidikan. Bandung: PT. Remaja Rosdakarya.

[6] Nanang Rahman. (2016). “Pengaruh model pembelajaran inkuiri berbasis home materials untuk meningkatkan motivasi belajar IPA terpadu siswa SMPN 1 Tanjung Kabupaten Lombok Utara". Jurnal Orbita. Vol 2, No.1 
Jurnal Elementary | Vol. 1, No. 1, Januari 2018, hal 1-4

[7] Salirawati, D. (2001). Materi Pelatihan Kepala Laboratorium Kimia bagi Guru-Guru Kimia Kabupaten Kulon Progo. Disampaikan di Laboratorium FMIPA UNY Yogyakarta, 1 Oktober 2011.

[8] Sumintono, B. 2010. "Pengajaran Sains dengan Praktikum Laboratorium: Perspektif dari Guru Sains SMPN di Kota Cimahi”. Jurnal Penelitian Pendidikan, Vol 15, No. 2.

[9] Tatat Hartati, dkk. (2009). Productive Pedagogy \& Subject Specific Pedagogy.Bandung: Universitas Pendidikan Indonesia (UPI) Bandung. 